\title{
Postnatal Leptin Surge and Regulation of Circadian Rhythm of Leptin by Feeding Implications for Energy Homeostasis and Neuroendocrine Function
}

\author{
Rexford S. Ahima, Daniel Prabakaran, and Jeffrey S. Flier \\ Department of Medicine, Division of Endocrinology, Beth Israel Deaconess Medical Center and Harvard Medical School, Boston, \\ Massachusetts 02215
}

\begin{abstract}
Leptin is thought to regulate energy balance through effects on food intake and thermogenesis. In addition, leptin may serve as a mediator of the neuroendocrine response to starvation, and may modulate the stress response and the timing of puberty. A role for leptin in development is suggested by the presence of neuroendocrine and structural neuronal abnormalities in $o b / o b$ mice with genetic leptin deficiency. Here, we sought to determine the ontogeny of leptin expression and its relationship to the developing neuroendocrine axis. Leptin increased 5-10-fold in female mice during the second postnatal week independent of fat mass, and declined after weaning. The rise in leptin preceded the establishment of adult levels of corticosterone, thyroxine, and estradiol. In contrast to adult mice, leptin was not acutely regulated by food deprivation during the early postnatal period. Circadian rhythms of leptin, corticosterone, and thyroxine were regulated by food intake in adult mice. When ad libitum feeding was restricted to the light cycle, peak corticosterone levels were shifted to the beginning of the light cycle and coincided with the nadir of leptin. The inverse relationship between leptin and corticosterone was maintained such that a rise in leptin after feeding was associated with a decline in corticosterone. To determine whether changes in corticosterone during food restriction are mediated by leptin, we compared the patterns of corticosterone levels among $o b / o b, d b / d b$, and lean mice. Despite their higher basal levels of corticosterone, leptin deficiency in $o b /$ $o b$ mice did not prevent the nocturnal rise in corticosterone. In contrast, the nocturnal surge of corticosterone was blunted in $d b / d b$ mice. Therefore, it is likely that factors in addition to leptin are involved in the regulation of the circadian rhythm of corticosterone. The temporal relationship between leptin and other hormones in neonatal and adult mice suggests that leptin is involved in the maturation and function of the neuroendocrine axis. (J. Clin. Invest. 1998. 101:1020-1027.) Key words: ob protein $\bullet$ corticosterone $\bullet$ thyroxine $\bullet$ development $\bullet$ diurnal rhythm
\end{abstract}

Address correspondence to Jeffrey S. Flier, M.D., Beth Israel Deaconess Medical Center (East Campus), Department of Medicine, Division of Endocrinology (Research North), 330 Brookline Avenue, Boston, MA 02215. Phone: 617-667-2151; FAX: 617-667-2927; E-mail: jflier@bidmc.harvard.edu

Received for publication 11 July 1997 and accepted in revised form 18 December 1997.

J. Clin. Invest.

(C) The American Society for Clinical Investigation, Inc. 0021-9738/98/03/1020/08 \$2.00

Volume 101, Number 5, March 1998, 1020-1027

http://www.jci.org

\section{Introduction}

The adipose-derived hormone leptin is thought to regulate energy homeostasis by stimulating coordinated changes in energy intake and expenditure in response to changes in energy stores (1-3). The importance of this function is evident in $o b /$ $o b$ mice, where total lack of leptin due to mutation of the leptin gene produces severe obesity from persistent hyperphagia and decreased energy expenditure (1-3). Although these findings created the expectation that leptin would be shown to function primarily as an antiobesity adipostatic hormone, recent research has suggested additional functions for this hormone. Among these roles are signaling the neuroendocrine response to starvation (4-6), the timing of puberty (7-9), and regulation of the hypothalamic-pituitary-adrenal (HPA) ${ }^{1}$ axis (10-13).

Two aspects of leptin biology that have received relatively little attention involve possible roles in early postnatal development and coordination of daily rhythms of hormone secretion. Regarding leptin and development, $o b / o b$ mice with complete leptin deficiency have evidence for developmental defects, including the failure to undergo sexual maturation $(14,15)$, as well as structural neuronal abnormalities and impaired myelination in the brain (16-18). These findings suggest that leptin may be involved in various aspects of central nervous system development. Maturation of neuronal pathways by leptin might require basal leptin levels or an increase in leptin at some critical period, independent of its later role as a sensor of energy stores. Since recent studies have shown that leptin treatment can accelerate puberty in normal prepubertal mice $(7,8)$, and that leptin levels increase before puberty in humans (19-21), we sought to characterize the pattern of leptin expression before initiation of sexual maturation in normal mice. Regarding leptin and circadian hormone secretion, studies in spontaneously feeding rodents and humans have revealed an inverse relationship between the levels of leptin and glucocorticoids (4, $22,23)$. Several lines of evidence suggest that leptin can regulate the HPA axis at the level of hypophysiotrophic corticotropin-releasing hormone and the adrenal gland (10-13). Since the circadian rhythm of the HPA axis is affected by feeding $(24,25)$, and diurnal levels of leptin are also influenced by food intake $(4,26)$, we sought to determine whether the inverse relationship between leptin and corticosterone would be retained in a restricted feeding paradigm, in a manner supporting a role for leptin as a modulator of the circadian rhythm of the HPA axis.

We show here that there is a discrete surge in leptin between 7 and $10 \mathrm{~d}$ in neonatal mice which is independent of fat mass or food intake, unlike the situation in adult mice $(4,27-$ 30). This temporal pattern of neonatal leptin, taken together

1. Abbreviation used in this paper: HPA, hypothalamic-pituitaryadrenal. 
with the previous demonstration of leptin effects on the HPA, thyroid, and gonadal axes, is consistent with the possibility that leptin plays a role in the poorly understood neuroendocrine events that occur at that time, such as the stress hyporesponsive period and the initiation of puberty. Results of the restricted feeding experiment confirm that leptin rhythms are influenced by feeding and are temporally related to alterations in the rhythms of corticosterone and thyroxine. However, the nocturnal rise in corticosterone was maintained in $o b / o b$ mice but blunted in $d b / d b$ mice, indicating that factors apart from leptin contribute the nocturnal rise of corticosterone in ad libitum-fed mice. These findings reveal previously unknown aspects of the regulation of leptin expression, and suggest that leptin may have developmental and neuroendocrine actions distinct from those related to energy homeostasis.

\section{Methods}

Ontogeny of leptin and relation to the adrenal, gonadal, and thyroid axes. Litters of female $\mathrm{C} 57 \mathrm{BL} / 6 \mathrm{~J}$ and $\mathrm{BALB} / \mathrm{c}$ mice (The Jackson Laboratory, Bar Harbor, ME) were housed ( $n=5$ per mother) in metal cages with constant environmental conditions, temperature $22^{\circ} \mathrm{C}$, and 12-h light (0600-1800) and 12-h dark (1800-0600) cycles. The experimental procedures were in accordance with guidelines of the Institutional Animal Care and Use Committee. The pups suckled ad libitum, and handling was limited to cage cleaning. They were weaned on regular laboratory chow at $21 \mathrm{~d}$. At various ages, groups of mice $(n=10)$ were weighed and killed by decapitation between 0900 and $1100 \mathrm{~h}$, and truncal blood was obtained for measurement of plasma leptin, insulin, corticosterone, thyroxine, and estradiol with RIA kits from Linco Research, Inc. (St. Charles, MO) and ICN Biomedicals, Inc. (Costa Mesa, CA) as described previously $(4,8)$. Plasma triglycerides were measured with an enzyme assay (Sigma Chemical Co., St. Louis, MO). Since the pups had little visible intraabdominal fat, subcutaneous white adipose tissue was dissected, and total RNA was extracted for measurement of $o b$ mRNA by Northern blot (29). Percent body fat was determined by carcass analysis as described previously $(30,31)$.

To determine the effect of maternal and food deprivation on leptin and corticosterone during the early postnatal period, 8-d-old pups were separated from their mothers for 3 and $12 \mathrm{~h}$, respectively $(n=5$ per group). For comparison, 12-wk-old female mice $(n=5)$ were food-restricted for $12 \mathrm{~h}$. The mice were killed by decapitation between 1000 and $1100 \mathrm{~h}$ of the light cycle, and truncal blood was obtained for measurement of plasma leptin and corticosterone (4). The data were analyzed by ANOVA and Fisher protected least significant difference test.

Effect of feeding and leptin on the circadian rhythm of corticosterone. The effect of food restriction on the circadian rhythm of corticosterone and the corresponding changes in leptin, thyroxine, and insulin was studied in female C57BL/6J mice age $10 \mathrm{wk}$. They were housed as described above, and handling was limited. After initial weights were measured, the mice were divided into two groups $(n=$ 40). One group was fed ad libitum, and the other was allowed access to chow for $4 \mathrm{~h}$ of the light cycle (1100-1500). Body weight and amount of chow consumed were measured between 0900 and $1000 \mathrm{~h}$. After $2 \mathrm{wk}$, groups of mice $(n=8)$ were killed by decapitation at 0600, 1000, 1600, 2000, and $2400 \mathrm{~h}$, and plasma leptin, corticosterone, thyroxine, and insulin were measured by RIA (4).

The role of leptin in the circadian rhythm of corticosterone was studied in female $o b / o b$ and $d b / d b$ mice (The Jackson Laboratory), ages 8 and $20 \mathrm{wk}$, respectively. The mice were housed as described above, fed ad libitum, and were allowed free access to water. Groups of mice $(n=4)$ were killed by decapitation at $0600,1200,1800$, and $2400 \mathrm{~h}$, and plasma leptin and corticosterone were measured by RIA. To further characterize the interrelationship between leptin and hor- mones involved in energy homeostasis, we compared the acute effect of leptin on corticosterone, insulin, and thyroxine. Groups of female $o b / o b$ mice ( $n=5$ per group) were injected intraperitoneally (i.p.) with either $100 \mu \mathrm{g}$ recombinant murine leptin (Eli Lilly and Co., Indianapolis, IN), in $100 \mu \mathrm{l}$ saline i.p., or three doses of leptin $6 \mathrm{~h}$ apart, or saline vehicle alone. The mice were killed $6 \mathrm{~h}$ later, and plasma corticosterone, leptin, and thyroxine were measured by RIA. The data were analyzed by ANOVA and Fisher protected least significant difference test.

\section{Results}

Fig. 1, $A-F$ illustrates the changes in body weight, body fat, leptin, and other hormones in C57BL/6J mice during the postnatal period. Body weight increased linearly (Fig. $1 A$ ); however, percent body fat was not altered significantly (Fig. $1 B$ ). Plasma leptin increased 5-10-fold to a peak level of $50 \pm 10 \mathrm{ng} / \mathrm{ml}$ in 10-d-old mice and decreased to adult levels after weaning (Fig. $1 A$ ). The rise in plasma leptin (Fig. $1 A$ ) coincided with a 6-10-fold increase in $o b$ mRNA in dorsal white adipose tissue (Fig. 1 B). Similarly, plasma leptin increased in female BALB/c mice independent of percentage of body fat (data not shown). Peak plasma leptin, $35 \pm 6 \mathrm{ng} / \mathrm{ml}$, was detected in 10 -d-old $\mathrm{BALB} / \mathrm{c}$ mice. Plasma triglycerides were elevated slightly in the first week $(107 \pm 14 \mathrm{mg} / \mathrm{dl})$ compared with the postweaning period $(88 \pm 7 \mathrm{mg} / \mathrm{dl})$; however, the difference was not statistically significant. In contrast to leptin, there was no significant change in plasma insulin (Fig. $1 D$ ). The leptin surge preceded the establishment of adult levels of corticosterone, estradiol, and thyroxine. Corticosterone levels were low in the second week and increased to adult levels after day 18 (Fig. $1 \mathrm{C}$ ). Estradiol was undetectable until day 14 and increased progressively to adult levels by day 34 (Fig. $1 E$ ). Thyroxine was low in the first week, increased nearly twofold to a peak of $11.2 \pm 0.75$ $\mu \mathrm{g} / \mathrm{dl}$ on day 12 , and decreased to adult levels after weaning (Fig. $1 F$ ).

Leptin and corticosterone were not altered significantly in neonatal mice deprived of food for $12 \mathrm{~h}$ (Fig. 2, $A$ and $B$ ). In contrast, leptin decreased by $40 \%$, and corticosterone increased sixfold in adult mice (Fig. 2, $C$ and $D$ ). Restriction of ad libitum feeding in adult mice to $4 \mathrm{~h}$ of the light cycle (1100$1500 \mathrm{~h}$ ) resulted in a $17 \%$ decrease in body weight by day 4 (Fig. 3 A). Food intake decreased to $50 \%$ by the second day of food restriction and increased thereafter, leading to normalization of body weight after day 8 (Fig. $3 \mathrm{~B}$ ). There was a reciprocal relation between diurnal levels of corticosterone and leptin in ad libitum-fed mice. Corticosterone peaked at 2000-2400 h during the dark cycle and decreased to a nadir at the beginning of the light cycle (Fig. $4 \mathrm{~A}$ ). Conversely, plasma leptin decreased during the light cycle and peaked late in the dark cycle (Fig. 4 B). After 2 wk during which ad libitum feeding was restricted to the light cycle, corticosterone decreased to a nadir $1 \mathrm{~h}$ after feeding $(1600 \mathrm{~h})$, increased during the rest of the light and dark cycles, and peaked at the beginning of the next light cycle (Fig. $4 A$ ). In contrast, leptin surged after feeding and decreased shortly thereafter (Fig. $4 B$ ). Peak plasma leptin coincided with the nadir of corticosterone (Fig. 4, $A$ and $B$ ). Insulin and thyroxine were higher during the dark and light cycles, respectively, in ad libitum-fed mice (Fig. 4, $C$ and $D$ ). As with corticosterone and leptin, there was a parallel shift in diurnal levels of insulin and thyroxine after 2 wk of restricted feeding. Peak insulin levels shifted to the light cycle (1600 h) (Fig. 4 C), 

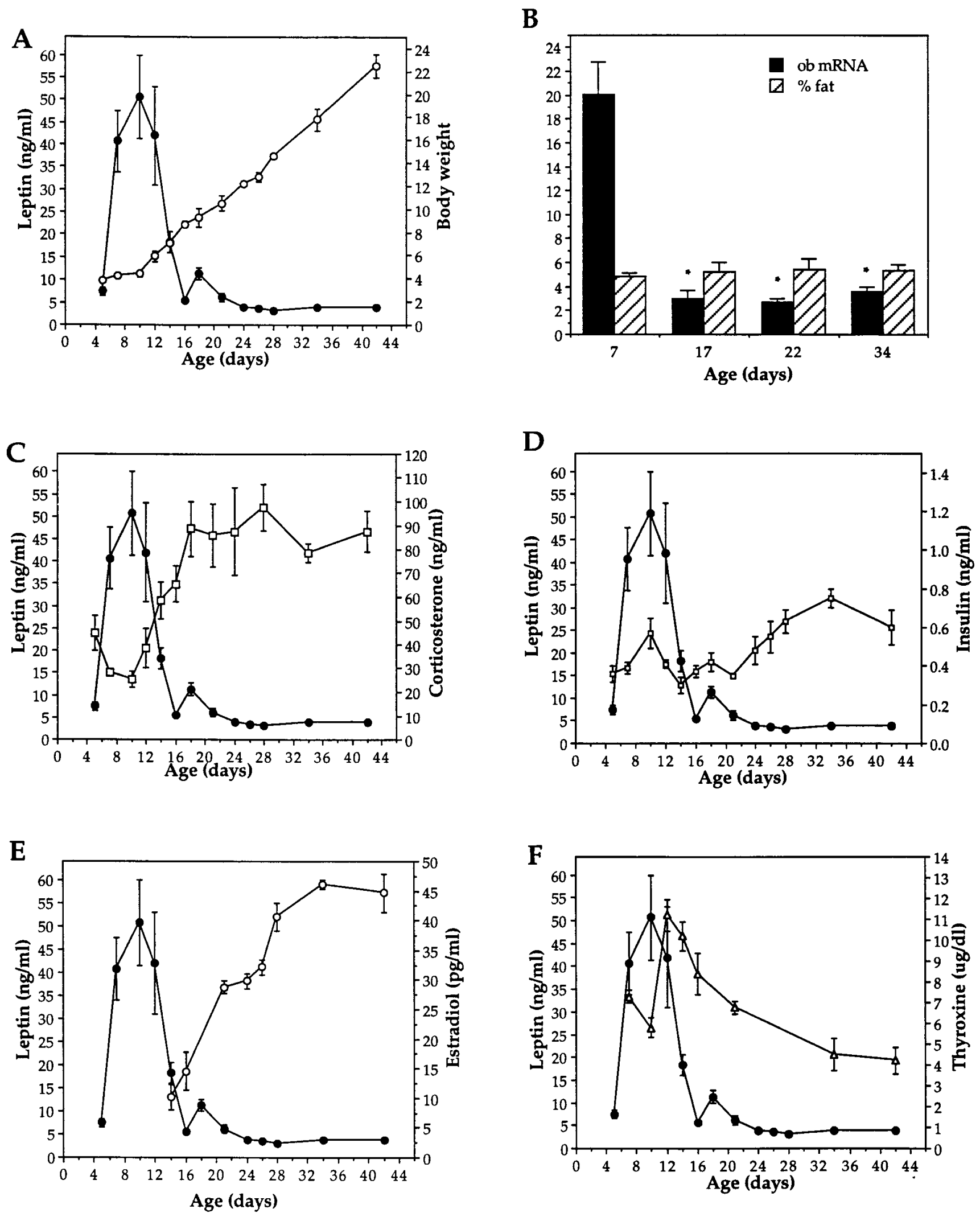

Figure 1. Ontogeny of leptin in female C57BL/6J mice (filled circles) and relationship to $(A)$ growth curve, $(B)$ body fat, $(C)$ corticosterone, $(D)$ insulin, $(E)$ estradiol, and $(F)$ thyroxine. Values represent means \pm SEM; $n=5-10$. For $o b$ mRNA, values represent arbitrary densitometric units, $* P<0.05$ compared with day 7 . 

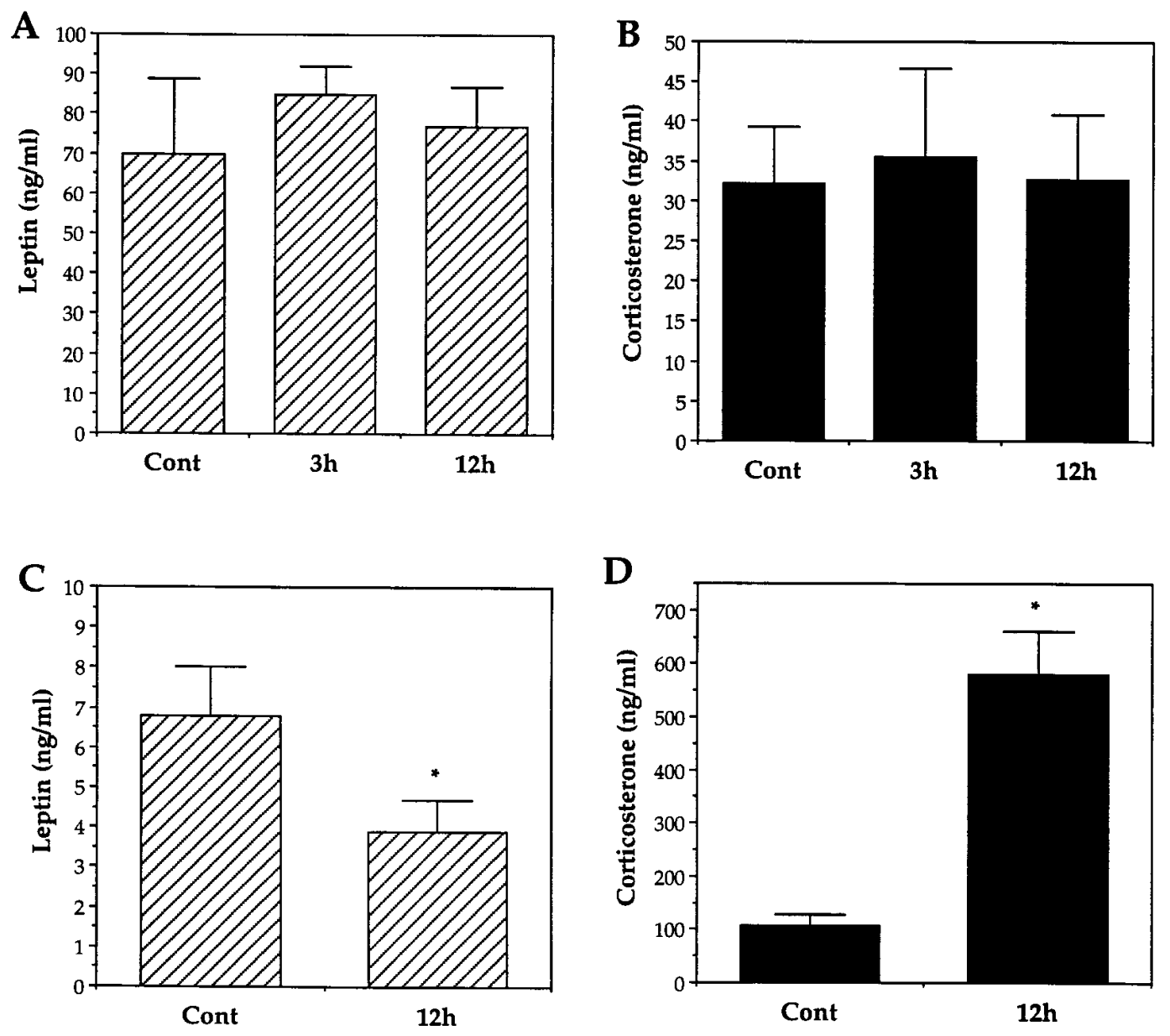

Figure 2. Effect of food
deprivation on plasma
leptin and corticosterone
in 8 -d-old $(A$ and $B)$ and
adult $(C$ and $D)$ female
C57BL $/ 6 \mathrm{~J}$ mice. Values
represent means $\pm S E M$;
$n=5, * P<0.05$ com-
pared with fed mice.
Cont, Controls.

while the zenith for thyroxine shifted to the dark cycle (24000600 h) (Fig. 4 D).

To determine whether changes in the patterns of corticosterone associated with food intake in adult mice were mediated in part by leptin, we measured corticosterone levels in ad libitum-fed $o b / o b$ and $d b / d b$ mice. Basal corticosterone levels were $85 \%$ higher in 8 -wk-old $o b / o b$ and 5-10-fold higher in 20wk-old $d b / d b$ mice compared with lean controls (Fig. 5, $A$ and $B)$. As with normal mice, there was a rise in corticosterone during the dark cycle in $o b / o b$ mice (Fig. $5 A$ ). In contrast, the nocturnal surge of corticosterone was blunted in $\mathrm{db} / \mathrm{db}$ mice (Fig. 5 B). Acute effects of leptin on metabolic hormones were studied further in $o b / o b$ mice. Plasma insulin decreased by $48 \%$ from $14.1 \pm 2.04$ to $7.3 \pm 1.6 \mathrm{ng} / \mathrm{ml} 6 \mathrm{~h}$ after a single leptin injection, and by $73 \%$ after three injections. In contrast, corticosterone and thyroxine were not altered significantly by a single injection of leptin. After three injections of leptin, corticosterone decreased by $44 \%$, from $345 \pm 52$ to $190 \pm 18 \mathrm{ng} / \mathrm{ml}$, and thyroxine increased by $48 \%$, from $2.4 \pm 0.2$ to $3.6 \pm 0.3 \mu \mathrm{g} / \mathrm{dl}$ (Fig. 5 C).

\section{Discussion}

These studies provide new insight into the ontogeny of leptin and its relationship to the neuroendocrine axis during the neonatal period and after weaning. We have demonstrated in two mouse strains that plasma leptin and $o b$ mRNA increase

markedly during the early postnatal period in female mice and then fall rapidly to adult levels after weaning. The regulation of leptin during the early postnatal period is distinct from that observed in adult mice in a number of respects. First, while leptin levels are known to increase in proportion to adiposity in fed mice $(27,28)$, the percentage of body fat was stable during the neonatal period during which the leptin surge was observed. Second, in contrast to adult mice $(4,29)$, the postnatal leptin surge was not blunted or prevented acutely by food deprivation. Studies published subsequent to our submission have also demonstrated a rise in leptin in neonatal mice and rats $(32,33)$. Devaskar et al. (32) detected a two- to fivefold increase in $o b$ mRNA and a fourfold rise in plasma leptin in $\mathrm{BALB} / \mathrm{c}$ mice between 2 and $7 \mathrm{~d}$ of age, with a decline in leptin after day 14 . We observed a greater increase in $o b$ mRNA and plasma leptin in both $\mathrm{C} 57 \mathrm{BL} / 6 \mathrm{~J}$ and BALB/c mice between 7 and $10 \mathrm{~d}$ in this study. While both studies agree that leptin levels are higher during the neonatal period independent of body weight, differences in the timing and magnitude of peak leptin levels in neonatal mice may depend on the strain of mice as well as the age at which samples are obtained. Devaskar et al. (32) suggested that increased leptin levels in neonatal mice may reflect the high fat content of milk diet during suckling. However, this is unlikely, since we did not detect a significant rise in plasma triglyceride levels or body fat in the early postnatal period.

A rise in leptin during the postnatal period has also been 

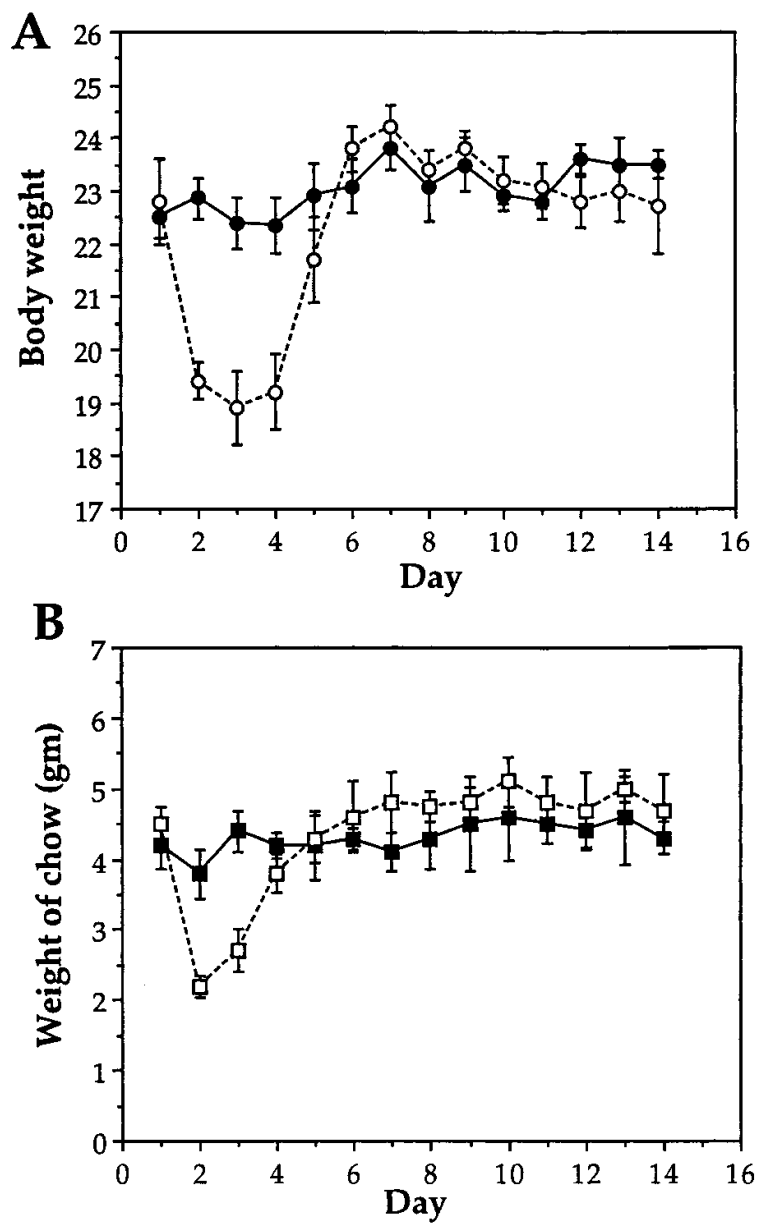

Figure 3. Changes in $(A)$ body weight and $(B)$ food intake during food restriction in adult female C57BL/6J mice. Closed symbols, ad libitum-fed; open symbols, allowed to feed ad libitum from 1100 to $1500 \mathrm{~h}$. Values are means \pm SEM; $n=40$.

demonstrated in obese ( $f a / f a)$ rats and lean littermates (33). As with mice in this study, leptin levels were highest during the second postnatal week in $f a / f a$ and normal rats. Baseline leptin levels were higher in leptin resistant $f a / f a$ compared with normal rats, and a second surge in leptin coincident with the obese phenotype was observed after weaning. While the functional significance of the increase in leptin in neonatal mice and rats is not known, a possible mechanism underlying the rise in leptin is decreased leptin receptor sensitivity. The detection of higher basal leptin levels in fa/fa rats before the development of obesity is consistent with this view; however, the leptin surge suggests the involvement of other factors apart from leptin receptors. Although glucocorticoids and insulin are known to be positive regulators of leptin expression $(26,34-37)$, the rise in leptin in neonatal mice is unlikely to have been stimulated by insulin or glucocorticoids, since we found no significant change in insulin, and the surge in leptin preceded the rise in corticosterone. Further studies will be needed to better understand the mechanisms underlying the postnatal leptin surge.

Recent studies on the ontogeny of leptin in humans also raise the possibility that leptin has a developmental role. A positive correlation between birth weight and neonatal leptin concentration has been described (20). Leptin concentration in cord blood of full-term infants in one study was severalfold higher than previously reported levels in nonobese adults (21, 38). A longitudinal study in boys has also demonstrated a prepubertal rise in leptin levels (19). As with the current study in mice, the increased level of leptin in boys was independent of adipose mass and did not appear to be regulated by adrenal steroids (19). In contrast to humans, a prepubertal rise in leptin was not observed in rhesus monkeys (39). The temporal association between the timing of the leptin surge and changes in levels of adrenal, thyroid, and gonadal hormones does not directly establish a role for leptin in these neuroendocrine changes. However, given the ability of leptin administration to both $o b / o b$ and normal animals to regulate the HPA, gonadal, and thyroid axes in the direction observed in postnatal mice $(4-13,40)$, it is reasonable to hypothesize that increased leptin expression during the early postnatal period serves as one factor producing the observed postnatal changes in the neuroendocrine axis. Additional experiments will be required to further test this hypothesis.

Taken together with the presence of neuroendocrine (41), autonomic (42), structural neuronal abnormalities $(16,17)$ and impaired myelination (18) in $o b / o b$ mice with genetic leptin deficiency, it is possible that leptin exerts a developmental role. Since hypothermia, hyperadrenalism, and hypogonadism in adult $o b / o b$ mice can be reversed by leptin treatment $(2,14$, $15,40)$, it appears that the autonomic and neuroendocrine targets of leptin in the brain retain the ability to respond even when leptin exposure is delayed. There are precedents for hormones with both activational and organizational actions on the brain during the postnatal period and in adults. For example, glucocorticoids, estrogen, and thyroid hormones regulate the synthesis and release of neurotransmitters as well as neurogenesis and neuronal plasticity in postnatal and adult brains (43). Hormones can also influence the development of other neuroendocrine systems during the neonatal period. For example, in addition to its well-known role in myelination (44), thyroxine modulates neonatal pituitary and adrenocortical function (45). The expression of high levels of leptin in the placenta (46, 47) and several fetal tissues (47) and demonstration that leptin regulates the differentiation of hemopoietic cells $(48,49)$ are in agreement with developmental roles for this hormone.

This study also provides new information on the interrelationships among food intake, leptin, and other metabolic hormones in the neonatal period and after weaning. In normal adult mice housed under 12-h light and 12-h dark cycles and fed ad libitum, maximum food intake occurs during the dark cycle (4). Glucocorticoids increase early in the dark cycle, coinciding with the onset of feeding, and decrease to a nadir at the beginning of the light cycle $(4,24,25)$. Conversely, plasma leptin peaks late in the dark cycle and decreases during the light cycle $(4,26)$. A reciprocal relation between diurnal levels of leptin and glucocorticoids has also been described in humans $(22,23)$. Plasma leptin levels appear to be pulsatile and circadian (23), and leptin peaks early in the dark cycle, whereas cortisol peaks before wakefulness $(22,23)$. In agreement with previous studies $(4,29)$, fasting resulted in a decrease in leptin and an increase in corticosterone in adult mice. In contrast, leptin and corticosterone were not altered after $12 \mathrm{~h}$ of maternal and food deprivation in 8-d-old pups. The reasons for this age-dependent difference in the response of leptin and the 
A
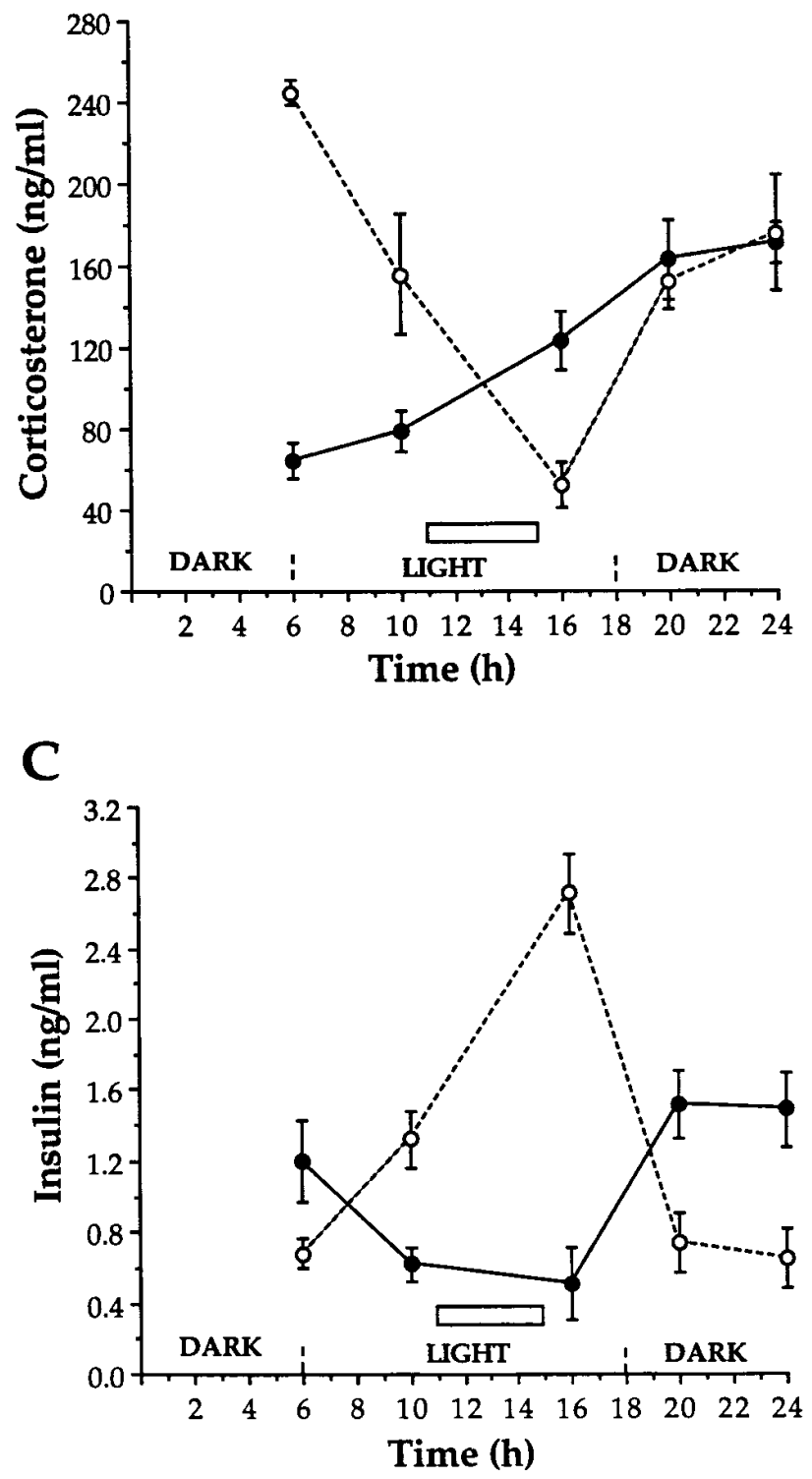

B

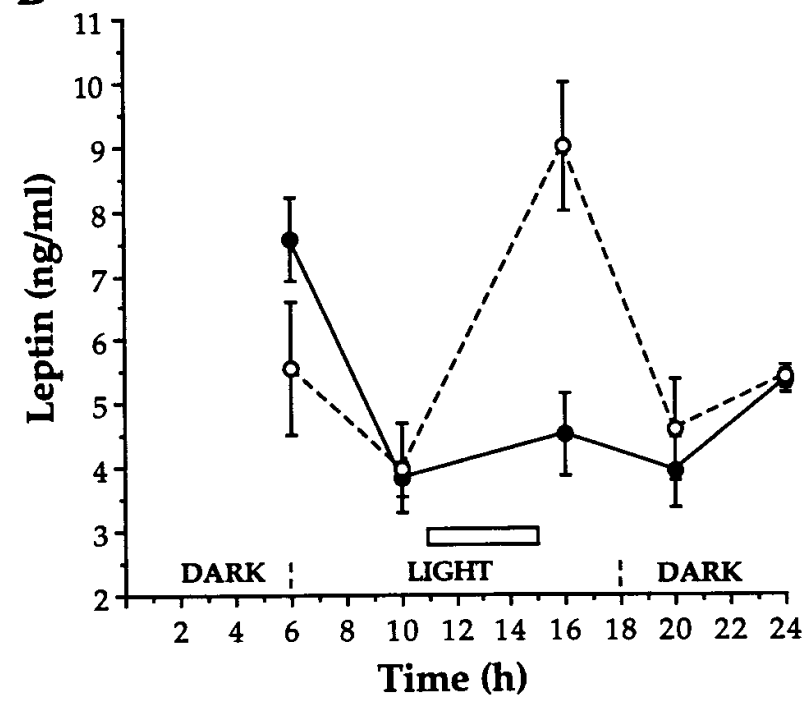

D

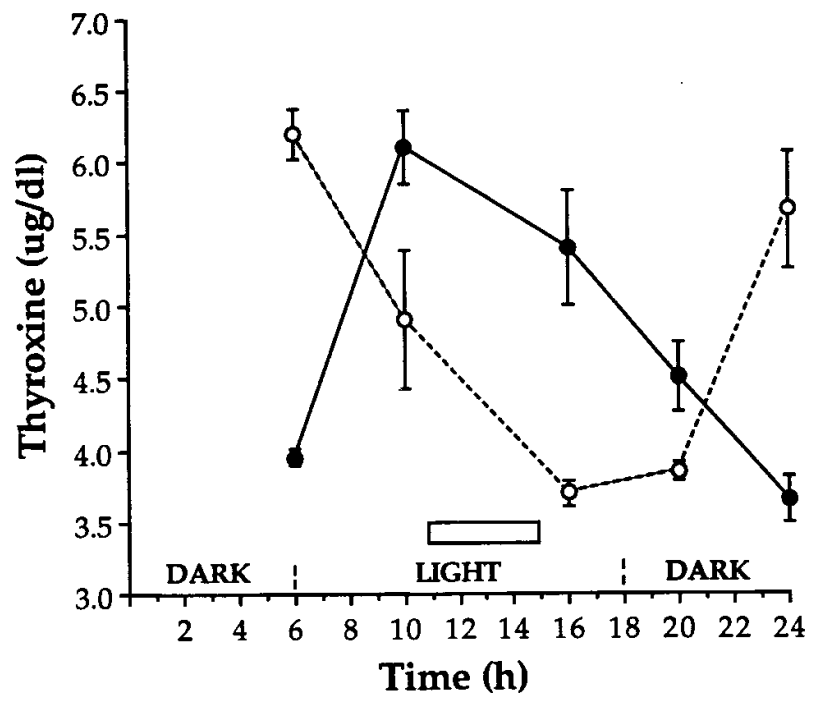

Figure 4. Comparison of circadian patterns of $(A)$ corticosterone, $(B)$ leptin, $(C)$ insulin, and $(D)$ thyroxine between ad libitum-fed (filled circles) and food-restricted mice (open circles). Inset box, Period of food restriction (1100-1500 h). Values represent means \pm SEM; $n=6-8$.

HPA axis to starvation are not known. Possible mechanisms may include immaturity of feedback mechansims for leptin and glucocorticoids, as well as differences in the rates of synthesis, secretion, or clearance of these hormones. The blunted response of the HPA axis to various stressors during the stress hyporesponsive period in neonates is well-known (50) and is thought to result in part from immaturity of feedback mechanisms (50). Similarly, it is possible that the persistence of higher levels of leptin in pups after $12 \mathrm{~h}$ of food deprivation is reflective of the absence of fully functional leptin receptors.

In agreement with previous studies $(24,25)$, the circadian rhythm of corticosterone in adult mice was regulated by feeding. After 2 wk of restriction of feeding to the light cycle, corticosterone decreased to a nadir after feeding, increased during the rest of the light and dark cycles, and peaked before the next meal. The reciprocal relation between leptin and glucocorticoids was maintained, and there was a parallel shift of the timing of peak levels of corticosterone and leptin. Leptin is capable of altering corticosterone acutely; however, since a circadian rhythm of corticosterone is present in $o b / o b$ mice, it is likely that other factors mediate changes in corticosterone levels associated with feeding. As with obese Zucker rats (51), leptin resistance in $d b / d b$ mice was marked by high baseline corticosterone levels and absence of a circadian rhythm. In contrast, Saito and Bray (52) observed a nocturnal increase in corticosterone in both $o b / o b$ and $d b / d b$ mice. The discrepancy between our findings and those of the previous study (52) could have arisen from the age difference between the animals. Our $d b / d b$ mice were older, and this may have altered the response of the HPA axis. 

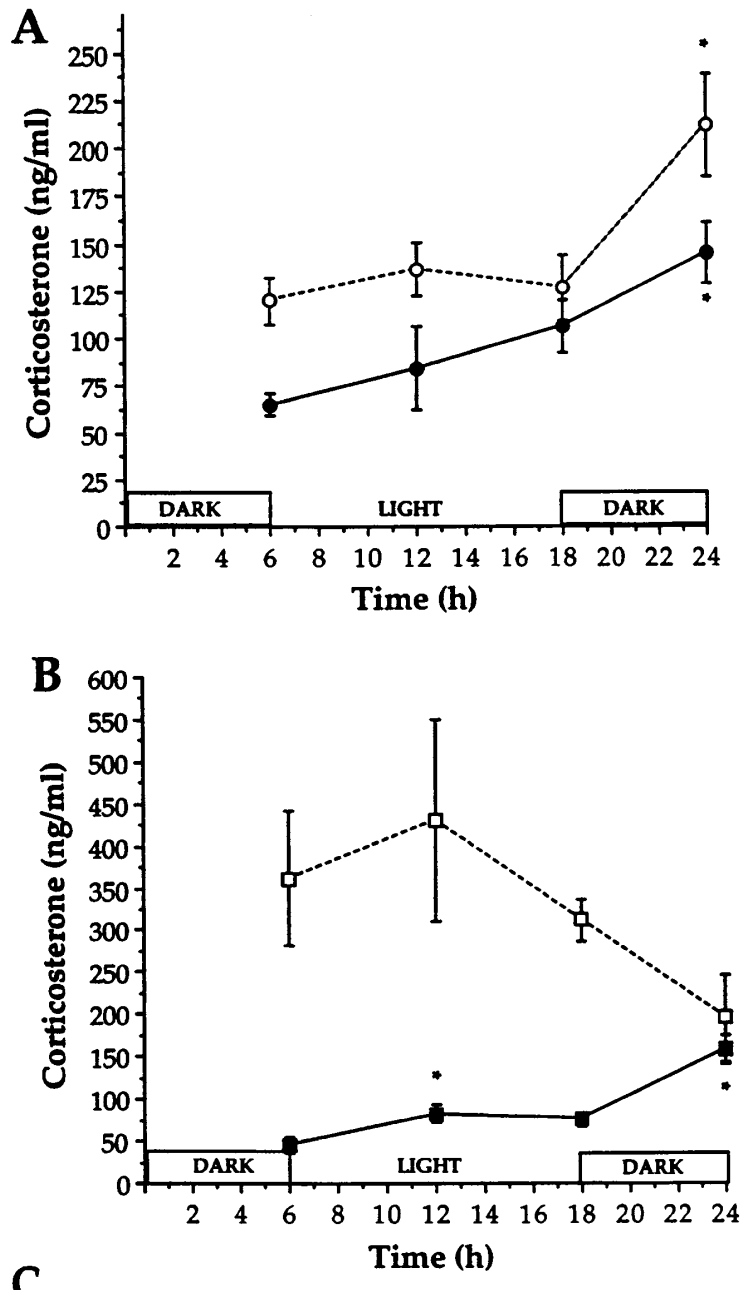

C

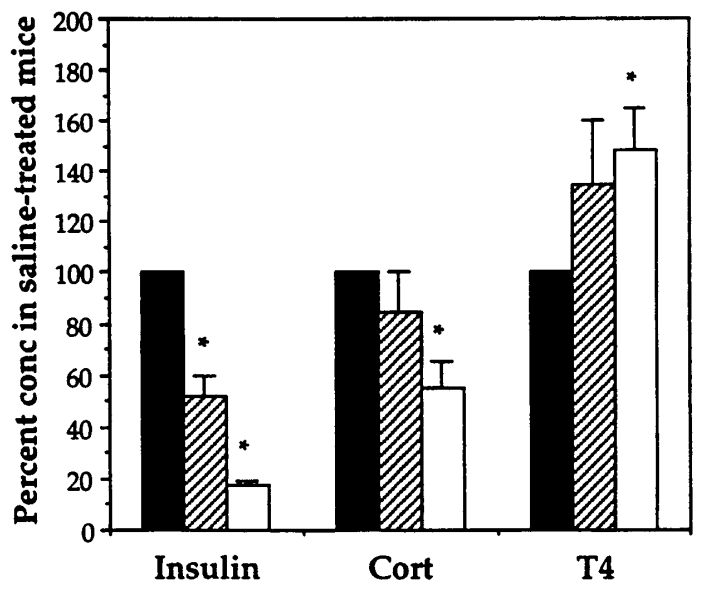

Figure 5. Comparison of corticosterone levels in $(A)$ ob/ob (open circles) and (B) db/db mice (open squares) to lean ( $+/$ ?) controls (filled symbols); values represent means \pm SEM, $n=4, * P<0.05$ compared with 0600 h. (C) Comparison of acute effects of i.p. leptin injection on plasma insulin, corticosterone (Cort), and thyroxine (T4) in 8-wk-old female $o b / o b$ mice ( $n=5$ per group). Values represent percentage of concentration in saline-treated mice \pm SEM. $* P<0.05$ compared with saline-treated mice. Black bars, Saline. Striped bars, Leptin 6 h. White bars, Leptin $24 \mathrm{~h}$.
Along with the changes in leptin and corticosterone, there were significant alterations in the levels of thyroxine and insulin as a result of food restriction in adult mice. In agreement with a previous study (53), we detected peak thyroxine levels during the light cycle in ad libitum-fed adult mice. The peak thyroxine level shifted from the light to dark cycle during food restriction. Peak leptin levels preceded the rise in thyroxine during food restriction; however, we did not determine the direct role of leptin in the alteration of thyroxine levels. Based on previous studies on the ability of leptin to restore thyroid hormones in fasted rodents $(4,5)$, and to acutely increase thyroxine in $o b / o b$ mice, we hypothesize that leptin may be a mediator of changes in the thyroid axis during food restriction. Changes in the thyroid hormones could contribute to energy homeostasis through regulation of thermogenesis. The ability of adult mice eventually to normalize and maintain body weight despite a shorter feeding period is likely the result of a complex interaction between peripheral signals such as insulin, leptin, and glucocorticoids and brain centers involved in the regulation of feeding behavior and energy expenditure.

In summary, the temporal relationship between leptin and other hormones suggests that leptin hyperexpression in the early postnatal period may play a role in the development and function of the neuroendocrine axis that is independent of its later role as a signal that transduces information regarding energy stores and balance to the brain. This putative role of leptin requires that its expression be regulated in a manner distinct from its regulation in postweaning life. During the postweaning period, leptin likely cooperates with other peripheral signals such as insulin and glucocorticoids to provide important signals that link the availability of energy stores to neural targets in the brain.

\section{Acknowledgments}

This study was supported by National Institutes of Health grant DKR3728082 to J.S. Flier, and by a grant from Eli Lilly and Company.

\section{References}

1. Campfield, L.A., F.J. Smith, Y. Guisez, R. Devos, and P. Burn. 1995. Recombinant mouse $\mathrm{OB}$ protein: evidence for a peripheral signal linking adiposity and central neural networks. Science. 269:546-549.

2. Pelleymounter, M., M. Cullen, M. Baker, R. Hecht, D. Winters, T. Boone, and F. Collins. 1995. Effects of the obese gene product on body weight regulation in ob/ob mice. Science. 269:540-543.

3. Halaas, J., K. Gajiwala, M. Maffei, S. Cohen, B. Chait, D. Rabinowitz, R. Lallone, S. Burley, and J. Friedman. 1995. Weight-reducing effects of the plasma protein encoded by the obese gene. Science. 269:543-546.

4. Ahima, R.S., D. Prabakaran, C. Mantzoros, D. Qu, B. Lowell, E. Maratos-Flier, and J.S. Flier. 1996. Role of leptin in the neuroendocrine response to fasting. Nature. 382:250-252.

5. Legradi, G., C.H. Emerson, R.S. Ahima, J.S. Flier, and R.M. Lechan. 1997. Leptin prevents fasting-induced suppression of prothyrotropin-releasing hormone messenger ribonucleic acid in neurons of the hypothalamic paraventricular nucleus. Endocrinology. 138:2569-2576.

6. Carro, E., R. Senaris, R.V. Considine, F.F. Casanueva, and C. Dieguez. 1997. Regulation of in vivo growth hormone secretion by leptin. Endocrinology. 138:2203-2206.

7. Chehab, F.F., K. Mounzih, R. Lu, and M.E. Lim. 1997. Early onset of reproductive function in normal female mice treated with leptin. Science. 275:88-90.

8. Ahima, R.S., D. Dushay, S.N. Flier, D. Prabakaran, and J.S. Flier. 1997. Leptin accelerates the onset of puberty in normal female mice. J. Clin. Invest. 99:391-395.

9. Cheung, C.C., J.E. Thornton, J.L. Kuijper, D.K. Clifton, and R.A. Steiner. 1997. Leptin is a metabolic gate for onset of puberty in the female rat. Endocrinology. 138:855-858.

10. Heiman, M.L., R.S. Ahima, L.S. Craft, B. Schoner, T.W. Stephens, and J.S. Flier. 1997. Leptin inhibition of the hypothalamic-pituitary-adrenal axis in 
response to stress. Endocrinology. 138:3859-3863.

11. Bornstein, S.R., K. Uhlmann, A. Haidan, M. Ehrhart-Bornstein, and W.A. Scherbaum. 1997. Evidence for a novel peripheral action of leptin as a metabolic signal to the adrenal gland: leptin inhibits cortisol release directly. Diabetes. 46:1235-1238.

12. Costa, A., A. Poma, E. Martignoni, G. Nappi, E. Ur, and A. Grossman. 1997. Stimulation of corticotropin-releasing hormone release by obese $(o b)$ gene product, leptin, from hypothalamic explants. Neuroreport. 8:1131-1134.

13. Raber, J., S. Chen, L. Mucke, and L. Feng. 1997. Corticotropin-releasing factor and adrenocorticotropic hormone as potential central mediators of OB effects. J. Biol. Chem. 272:15057-15060.

14. Chehab, F., M. Lim, and R. Lu. 1996. Correction of the sterility defect in homozygous obese female mice by treatment with the human recombinant leptin. Nat. Genet. 12:318-320.

15. Barash, I.A., C.C. Cheung, D.S. Weigle, R. Hongping, E.B. Kagigting, J.L. Kuijper, D.K. Clifton, and R.A. Steiner. 1996. Leptin is a metabolic signal to the reproductive system. Endocrinology. 137:3144-3147.

16. Bereiter, D.A., and B. Jeanrenaud. 1979. Altered neuranatomical organization in the central nervous system of the genetically obese $(o b / o b)$ mouse. Brain Res. 165:249-260.

17. Bereiter, D.A., and B. Jeanrenaud. 1980. Altered dendritic orientation of hypothalamic neurons from genetically obese $(o b / o b)$ mice. Brain Res. 202: 201-212.

18. Sena, A., L.L. Sarliene, and G. Rebel. 1985. Brain myelin of genetically obese mice. J. Neurol. Sci. 68:233-243.

19. Mantzoros, C.S., J.S. Flier, and A.D. Rogol. 1997. A longitudinal assessment of hormonal and physical alterations during normal puberty in boys. V. Rising leptin levels may signal the onset of puberty. J. Clin. Endocrinol. Metab. 82:1066-1070

20. Matsuda, J., I. Yokota, M. Iida, T. Murakami, E. Naito, M. Ito, K. Shima, and Y. Kuroda. 1997. Serum leptin concentration in cord blood: relationship to birth weight and gender. J. Clin. Endocrinol. Metab. 82:1642-1644.

21. Sivan, E., W.M. Lin, C.J. Homko, E.A. Reece, and G.B. Boden. 1997. Leptin is present in human cord blood. Diabetes. 46:917-919.

22. Sinha, M.K., J.P. Ohannesian, M.L. Heiman, A. Kriaucinnas, T.W. Stephens, S. Magosin, C. Marco, and J.F. Caro. 1996. Nocturnal rise of leptin in lean, obese, and non-insulin-dependent diabetes mellitus subjects. J. Clin. Invest. 97:1344-1347.

23. Licinio, J., C. Mantzoros, A.B. Negro, G. Cizza, M.-L. Wong, P.B. Bongiorno, G.P. Chrousos, B. Karp, C. Allen, J.S. Flier, and P.W. Gold. 1997. Human leptin levels are pulsatile and inversely related to pituitary-adrenal function. Nat. Med. 3:575-579.

24. Itoh, S., G. Katsuura, and R. Hirota. 1980. Conditioned circadian rhythm of plasma corticosterone in the rat induced by food restriction. Jpn. J. Physiol. 30:365-375.

25. Morimoto, Y., K. Arisue, and Y. Yamamura. 1977. Relationship between circadian rhythm of food intake and that of plasma corticosterone and effect of food restriction on circadian adrenocortical rhythm. Neuroendocrinology. 23:212-222.

26. Saladin, R., P. Devos, M. Guerre-Millo, A. Leturge, J. Girard, B. Staels, and J. Auwerx. 1995. Transient increase in obese gene expression after food intake or insulin administration. Nature. 377:527-529.

27. Maffei, M.J., J. Halaas, E. Rayussin, R.E. Pratley, G.M. Lee, Y. Zhang, H. Fei, S. Kim, R. Lallone, and S. Ranganathan. 1995. Leptin levels in human and rodent: measurement of plasma leptin and $o b$ RNA in obese and weightreduced subjects. Nat. Med. 1:1155-1161.

28. Frederich, R.C., A. Hamann, S. Anderson, B. Lollman, B.B. Lowell, and J.S. Flier. 1995. Leptin levels reflect body lipid content in mice: evidence for diet-induced resistance to leptin action. Nat. Med. 1:1311-1314.

29. Frederich, R.C., B. Lollman, A. Hamann, A. Napolitano-Rosen, B. Kahn, B.B. Lowell, and J.S. Flier. 1995. Expression of $o b$ mRNA and its encoded protein in rodents. J. Clin. Invest. 96:1658-1663.

30. Salmon, D.M.W., and J.P. Platt. 1985. Effect of dietary fat content on the incidence of obesity among ad libitum fed mice. Int. J. Obes. 9:443-449.

31. Moller, D.E., P.Y. Chang, B.B. Yaspelkis III, J.S. Flier, H. WallbergHenriksson, and J.H. Ivy. 1996. Transgenic mice with muscle-specific insulin resistance develop increased adiposity, impaired glucose tolerance and dyslipidemia. Endocrinology. 137:2397-2405.

32. Devaskar, S.U., C. Ollesch, R.A. Rajakumar, and P.A. Rajakumar. 1997. Developmental changes in $o b$ gene expression and circulating leptin pep- tide concentrations. Biochem. Biophys. Res. Commun. 238:44-47.

33. Rayner, D.V., G.D. Dagliesh, J.S. Duncan, L.J. Hardie, N. Hoggard, and P. Trayhurn. 1997. Postnatal development of the $o b$ gene system: elevated leptin levels in suckling fa/fa rats. Am. J. Physiol. 273:R446-R450.

34. Wabitsch, M., P.B. Jensen, W.F. Blum, C.T. Christoffersen, P. Englaro, E. Heinze, W. Rasscher, W. Teler, H. Tornqvist, and H. Hauner. 1996. Insulin and cortisol promote leptin production in cultured human fat cells. Diabetes. 45 : 1435-1438.

35. Utriainen, T., R. Malmstrom, S. Makimattila, and H. Yki-Jarvinen. 1996. Supraphysiological hyperinsulinemia increases plasma leptin concentrations after $4 \mathrm{~h}$ in normal subjects. Diabetes. 45:1364-1366.

36. Devos, P., R. Saladin, J. Auwerx, and B. Staels. 1995. Induction of $o b$ gene expression by corticosteroids is accompanied by body weight loss and reduced food intake. J. Biol. Chem. 270:15958-15961.

37. Slicker, J.J., K.W. Sloop, P.I. Surface, A. Kriauciunas, F. LaQuier, J. Manetta, J. Bue-Valleskey, and T.W. Stephens. 1996. Regulation of coexpression of $o b$ mRNA and protein by glucocorticoids and cAMP. J. Biol. Chem. 271:5301-5304.

38. Considine, R.V., M.K. Sinha, M.L. Heiman, A. Kriauciunas, T.W. Stephens, M.R. Nyce, J.P. Ohannesian, C.C. Marco, L.J. McKee, T.L. Bauer, and J.F. Caro. 1996. Serum immunoreactive leptin concentrations in normal weight and obese humans. N. Engl. J. Med. 334:292-295.

39. Plant, T.M., and A.R. Durrant. 1997. Circulating leptin does not appear to provide a signal for triggering the initiation of puberty in the male rhesus monkey (Macaca mulatta). Endocrinology. 138:4505-4508.

40. Stephens, T.W., M. Basinski, P.K. Bristow, J.M. Bue-Valleskey, S.G. Burgett, L. Craft, J. Hale, J. Hoffman, H.M. Hsiung, A. Kriauciunas, et al. 1995. The role of neuropeptide $\mathrm{Y}$ in the antiobesity action of the obese gene product. Nature. 377:530-532.

41. Garthwaite, T.L., D.R. Martinson, L.F. Tseng, T.C. Hagen, and L.A Menahan. 1980. A longitudinal hormonal profile of the genetically obese mouse. Endocrinology. 107:671-676.

42. Trayhurn, P., P.L. Thurlby, and W.P. James. 1977. Thermogenic defect in pre-obese $o b / o b$ mice. Nature. 266:60-62.

43. Gould, E., C.S. Woolley, and B.S. McEwen. 1991. The hippocampal formation: morphological changes induced by thyroid, gonadal and adrenal hormones. Psychoneuroendocrinology. 16:67-84.

44. Pasquini, J.M., and A.M. Adamo. 1994. Thyroid hormones and the central nervous system. Dev. Neurosci. 16:1-8.

45. Walker, C.D., P.C. Sizonenko, and M.L. Aubert. 1989. Modulation of the neonatal pituitary and adrenocortical response to stress by thyroid hormones in the rat: effects of hypothyroidism and hyperthyroidism. Neuroendocrinology. 50:265-273.

46. Masuzaki, H., Y. Ogawa, N. Sagawa, K. Hosoda, T. Matsumoto, H. Mise, H. Nishimura, Y. Yoshimasa, I. Tanaka, T. Mori, and K. Nakao. 1997. Nonadipose tissue production of leptin: leptin as a novel placenta-derived hormone in humans. Nat. Med. 3:1029-1033.

47. Hoggard, N., L. Hunter, J.S. Duncan, L.M. Williams, P. Trayhurn, and J.G. Mercer. 1997. Leptin and leptin receptor mRNA and protein expression in the murine fetus and placenta. Proc. Natl. Acad. Sci. USA. 94:11073-11078.

48. Mikhail, A.A., E.X. Beck, A. Shafer, B. Barut, J.S. Gbur, T.J. Zupancic, A.C. Schweitzer, J.A. Cioffi, G. Lacaud, B. Ouyang, et al. 1997. Leptin stimulates fetal and adult erythroid and myeloid development. Blood. 89:1507-1512.

49. Gainsford, T., T.A. Willson, D. Metcalf, E. Handman, C. McFarlane, A. Ng, N.A. Nicola, W.S. Alexander, and D.J. Hilton. 1996. Leptin can induce proliferation, differentiation and functional activation of hemopoietic cells. Proc. Natl. Acad. Sci. USA. 93:14564-14568.

50. Sapolsky, R.M., and M.J. Meaney. 1986. Maturation of the adrenocortical stress response: neuroendocrine control mechanisms and the stress hyporesponsive period. Brain Res. 396:64-76.

51. Martin, R.J., P.J. Wangsness, and J.H. Gahagan. 1978. Diurnal changes in serum metabolites and hormones in lean and obese Zucker rats. Horm. Metab. Res. 10:187-192.

52. Saito, M., and G.A. Bray. 1983. Diurnal rhythm for corticosterone in obese $(o b / o b)$, diabetes $(d b / d b)$ and gold thioglucose-induced obesity in mice. Endocrinology. 113:2181-2185.

53. Jordan, D., B. Rousset, F. Perrin, M. Fournier, and J. Orgiazzi. 1980 Evidence for circadian variations in serum thyrotropin, 3, 5, 3'-triiodothyronine and thyroxine in the rat. Endocrinology. 107:1245-1248. 